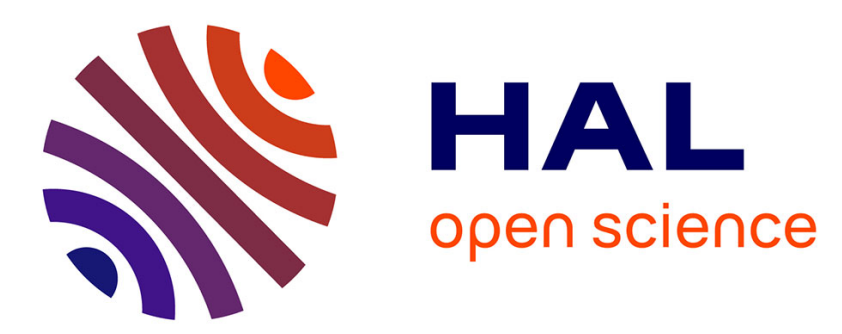

\title{
An economic interpretation of French military expenditures
}

Fanny Coulomb, Jacques Fontanel

\section{To cite this version:}

Fanny Coulomb, Jacques Fontanel. An economic interpretation of French military expenditures.

Defence and Peace Economics, 2005, 16 (4), pp.297-315. 10.1080/10242690500115915 . hal-02045742

HAL Id: hal-02045742

https://hal.univ-grenoble-alpes.fr/hal-02045742

Submitted on 22 Feb 2019

HAL is a multi-disciplinary open access archive for the deposit and dissemination of scientific research documents, whether they are published or not. The documents may come from teaching and research institutions in France or abroad, or from public or private research centers.
L'archive ouverte pluridisciplinaire HAL, est destinée au dépôt et à la diffusion de documents scientifiques de niveau recherche, publiés ou non, émanant des établissements d'enseignement et de recherche français ou étrangers, des laboratoires publics ou privés. 


\title{
An economic interpretation of French military expenditures
}

\author{
Fanny COULOMB ${ }^{1}$ and Jacques FONTANEL $* *^{2}$ \\ *CESICE : (Centre of Studies on International Security and European Community) \\ **PEPSE (Centre of Economic policy and social policy) \\ University Pierre Mendès France of Grenoble, France
}

The observation of French military expenditures since the 1990s may give rise to several questions. While the French policy remains characterized, according to the words of the President Jacques Chirac ${ }^{3}$, by the "will to assume (our) responsibilities on the international scene where (our) country is both awaited and respected", numerous criticisms are expressed against the insufficient means of the French defence or the increasing military "technological gap" between Europe and United States. An economic study of the evolution and structure of French military expenditures may contribute to explain this paradox; this will be the main subject of our paper.

There has been many changes in France's defence policy since 1945. Beside official speeches, the French "policy of grandeur" is no more relevant today. The history of French military expenditures is linked to the one of domestic arms production. The defence policy had been since long characterized by a search for "grandeur", with a great development of national arms industries during the Napoleon era, until the end of World War II. Afterwards, the Fifth Republic has increased the importance given to arms production and de Gaulle has opened the way to a new policy based on national independence thanks to nuclear weapons and the new concept of "proportional deterrence", and with the refusal of arms imports. Since 1966 and France's withdrawal from the integrated military command of NATO, the French defence has been specific, giving priority to the strategic autonomy and the territory inviolability, while other European countries had chosen the dependence with regard to United States. The control of the nuclear weapon after 1960 based a strategy of deterrence essentially oriented towards the East European socialist countries, while the conventional forces were prepared for a possible major confrontation. The arms production therefore became central in the industrial and technological development. The French arms industry was then highly competitive on international markets, in spite of some unefficiencies in the functioning of the "military-industrial complex", made of close relations between the engineers of the "Délégation Générale de l'Armement", the firms managers, and military staff. Arms exports were vital for the sector, as the size of production was not sufficient to realize economies of scale. They have been promoted even sometimes without any established economic or commercial logic. ${ }^{5}$

The new strategic context of the post-Cold war and the disappearance of the risk of direct military conflicts have led France to redefine its defence policy. The "White Book on Defence" of 1994 thus presented the necessity of adapting the military strategy to the new risks linked to the development of regional conflicts, of nuclear proliferation, and of chemical and bacteriological weapons. The scenarios of foreign interventions in the framework of "bilateral agreements of defence" or of "operations in favour of peace and international law" were also mentioned. In this context,

\footnotetext{
1 Lecturer of economics, University Pierre Mendès France of Grenoble, France, assistant director of CESICE-CEDSI, fanny.coulomb@upmf-grenoble.fr

${ }^{2}$ Professor of economics, University Pierre Mendès France of Grenoble, France, Director of PEPSE, Jacques.fontanel@upmf-grenoble.fr

3 "la volonté d'assumer (nos) responsabilités sur une scène internationale où notre pays est à la fois attendu et respecté” cérémonie des voeux pour 2004, www.defense.gouv.fr/sites/defense/base/autorites/voeux_de/

${ }^{4}$ Fontanel, J., Hébert, J.P., Coulomb, F.(2000), The restructuration of the French arms industry, paper presented at the Annual Conference of the American Economic Association, Boston, January, www.ecaar.org/Articles/fontanel.pdf

${ }_{5}^{5}$ Ministère de la Défense (2003), Annuaire statistique de la défense, Edition 2003., Cédérom, p.3.
} 
conventional weapons seemed essential, and there was an inversion of the immediate priorities between nuclear and conventional weapons ${ }^{6}$. The new strategy of action focused on the management of zones of crisis and on the European and international cooperation. Indeed, the French leaders had clearly advocated for an increased European cooperation and for the construction of an European defence.

In this context, France has always reasserted its military and strategic ambitions, as shown for example by the recent discourse of the chief of staff General Bentégeat ${ }^{7}$. Having insisted on the active role of France in the implementation of an Europe of defence, role which did not aspire to the leadership (what, according to her, "would be opposite to the philosophy of the European construction") but rather to a "co-piloting", the text outlines the bases of the French defence. However, "Since 1996, France has made the choice, which is inviolable and fundamental, to be a complete military power, by retaining a capacity of nuclear deterrence, by developing a capacity of intervention in all fields, as well as a capacity of command of a multinational operation.",

But beyond the declared objectives, one may think that the end of the cold war and the crisis of arms markets have led to the end of an independent military strategy. The defence budgets have indeed been dramatically reduced, in France like in other western countries, and the importance of military expenditures in the GNP has drastically decreased, as shown in table 1.

Tableau 1 : Share of defence expenditures in GNP (constant currency), (\%)

\begin{tabular}{|l|l|l|l|l|l|}
\cline { 2 - 6 }$\%$ & France & U.K. & Germany & Italy & United States \\
\hline Average 1990-94 & 3.4 & 3.9 & 2.1 & 2.1 & 4.7 \\
\hline $\mathbf{2 0 0 3}$ & 2.6 & 2.4 & 1.4 & 1.5 & 3.45 \\
\hline
\end{tabular}

Source : Ministère de la Défense, and NATO data ${ }^{9}$

The defence spending per capita in France decreased from 546 to 453 euro (constant 2003) from 1992 till 2003 and the defence budget of Initial Finance Law decreased by 4,46 \% in volume between 1992 and 2002. The reduction of the French defence budget is even more marked at the level of the budgetary execution ${ }^{10}$. At the same time as this reduction of military expenditures during decade 1990, the share of the defence sector in the domestic economy is declining. The part of the defence industry sales in the GDP did not stop decreasing since the mid-1980s, from 2,4\% to $0,8 \%$ between 1987 and 2000. Also, the arms exports represent no more than $0,21 \%$ of the GDP in 2001, as against $0,58 \%$ in $1990^{11}$. During the 1990's, the activity of defence underwent profound changes in France, with the opening to competition of arsenals, the privatizations of the arms firms and the rise in the number of partnerships between public sector and private sector.

In this context, does France still have the means of its ambitions? According to François Géré $^{12}$, the current French foreign policy is limited by the lack of military means; so in 2001, the decision not to send the aircraft carrier Charles de Gaulle to Afghanistan would have ensued from the technical impossibility to do so. But the political leaders as well as the military are reluctant to publicly recognize these inadequacies (mainly on equipments), notably resulting from bad strategic

\footnotetext{
${ }^{6}$ Hébert, J.P. (1998), 'La réforme de la politique de défense et l'industrie française d'armement', in Debezies, P., Klein, J., La réforme de la politique française de défense, Economica et Institut de Stratégie comparée, www.stratisc.org, site of the strategy in history.

${ }^{7}$ Declaration of the army general Henri Bentégeat, Chef d'état-major des armées, October $1^{\mathrm{st}}, 2004$, www.defense.gouv.fr/sites/ema/decouverte/le chef d'etat-major des armees/declarations/articles

8 "Depuis 1996, la France a fait le choix, intangible et fondamental, d'être une puissance militaire complète, en conservant une capacité de dissuasion nucléaire, en développant une capacité d'intervention dans tous les domaines ainsi qu'une capacité de commandement d'une opération multinationale.", op.cit.

${ }^{9}$ Ministère de la Défense (2003), Annuaire statistique de la défense, Edition 2003, Cédérom, chapter V.

${ }^{10}$ However since 2002 indicators show a rise in defence budget, as in most of the western countries.

${ }^{11}$ Ministère de la Défense (2003), Annuaire statistique de la défense, Edition 2003, Annexes.

${ }^{12}$ Géré, F. (2002), La défense française en 2002, Institut Diplomatie \& Défense, www.diploweb.com 
choices (like the continuation of the program of heavy tank Leclerc after 1991 for example). On the contrary, France multiplies the foreign operations, in Bosnia, Kosovo, Macedonia or Africa.

Although France's foreign policy remains characterized by the ambition to remain the leader country on European defence, the analysis of defence budgets reveals that the means have not always followed the declared objectives. One may then wonder about the determinants of French military expenditures. What is the place of economic determinants? Does France keep developing a coherent and distinctive defence policy? The analysis of statistical data on French military expenditures since 1990 turns out to be full of information on the determinants of military expenditures. Two arguments will be developed:

- While until the 1990s, French military expenditures have been considered as a national economic development force, now they more represent an economic shadow burden.

- The independent policy of security has been clearly replaced by a real dependency on armaments and strategies.

\section{I - French military expenditures, from an economic development force to an economic "shadow" burden}

Though in the past France has derived much advantages from the development of the military sector, now the situation is reversed. The changes in defence expenditures show some inertia effects and the difficulties to make the defence policy evolve. Military expenditures now seem to be more an economic burden than a driving force. The study of the defence budget compared with the general State budget shows that military expenditures are often used as variables of economic adjustment.

\section{I.1. The importance of inertia effects}

The influence on French military expenditures of external factors is difficult to estimate, in the lack of any avowed State enemy. The security function would be almost impossible to define in a model of military expenditures. Indeed, because of the variety of the instruments of foreign policy (diplomatic operations, interventions in regional conflicts, economic and military assistance, membership in an alliance), the taking into account of the action-reaction process in military expenditures is insufficient. As France's status in the NATO is particular, its strategy varies according to interests which are more European than Atlantic, more French than European. In this context, France strategies evolve according to the available instruments (diplomatic, military, political, notably). The French government uses all its trump cards in a very pragmatic way, exploiting alternately its membership in the Atlantic Pact and in the European Union while reminding its membership in the United Nations Security Council and its own nuclear force.

\section{1) A belated reduction compared with other NATO countries}

The French military expenditures have not been immediately affected by the end of the Cold War and the new geopolitical context. It is later that France begins a reduction of its defence budget, with regard to other NATO countries. It may be explained by the relative lateness of the defence policy reform and also by a political will to preserve the national independence on defence, and though to maintain a high level of military expenditures, in spite of the geopolitical changes.

So, between 1990 and 1994, the French military expenditures decreased only $0,7 \%$ a year on average, whereas this number was 6,3\% for Germany, 4,2 \% for United Kingdom and 5,3\% for United States, according to NATO data ${ }^{13}$. Also, between 1995 and1999, the decline was of $1,2 \%$ on annual average in France, against 1,7 \% in United Kingdom and 2,6 \% in United States. 
The study of NATO statistics shows that French military expenditures did not follow a trend similar to NATO's ones ( $c f$. Table 2 and Graph 1).

\section{Graph 1 :}

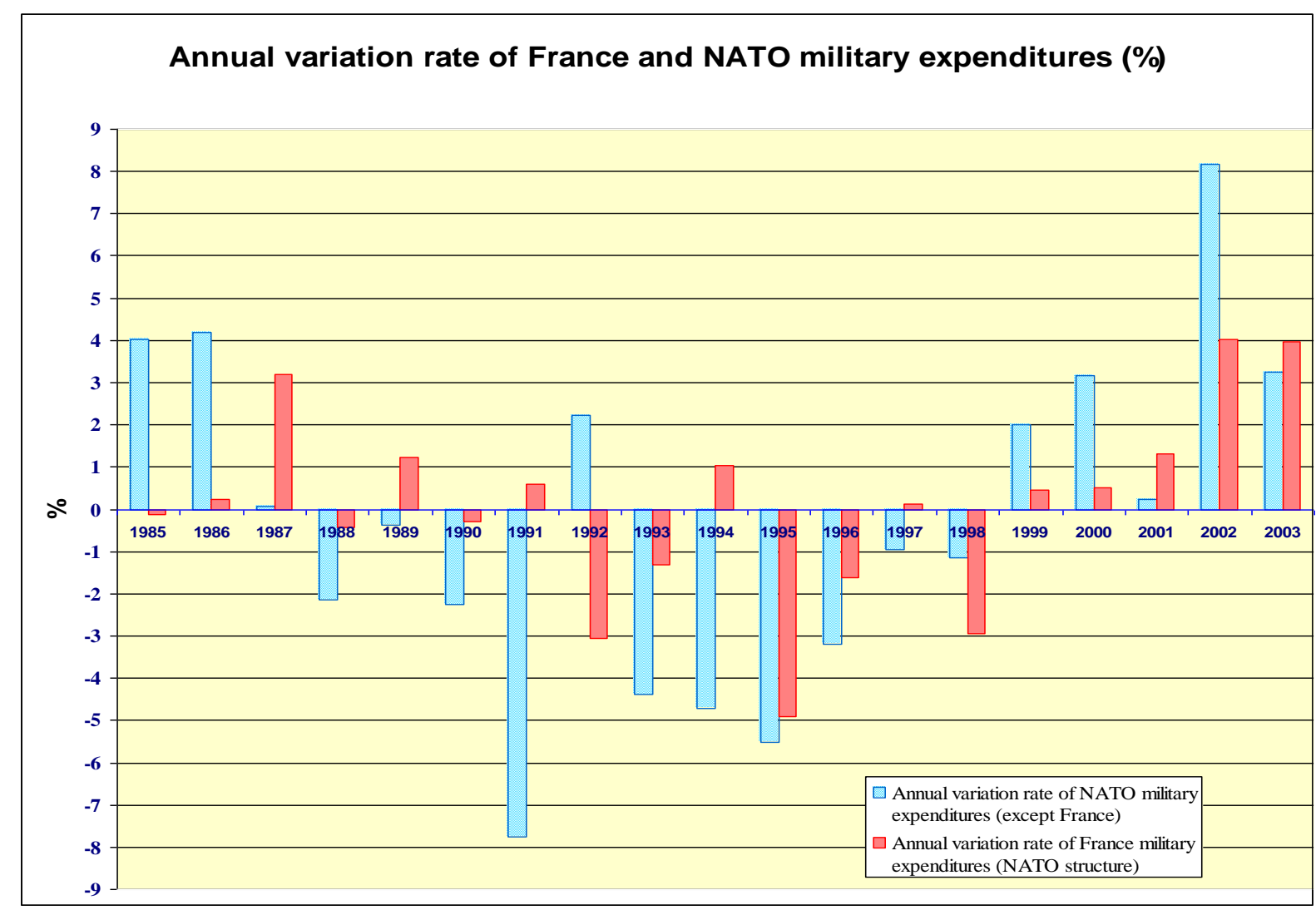

From NATO data ${ }^{14}$.

Table 2 : Defence spending, France, United States, NATO And their variation from the previous period (constant 1995 currency)

\begin{tabular}{|c|c|c|c|c|c|c|c|c|c|c|c|}
\hline & & 1975 & 1980 & 1985 & 1990 & 1995 & 1999 & 2000 & 2001 & 2002 & 2003 \\
\hline France & $\begin{array}{c}\text { Euros } \\
\text { (Million) }\end{array}$ & 27860 & \begin{tabular}{|l|}
33670 \\
$+20,8 \%$ \\
\end{tabular} & \begin{tabular}{|l|}
37361 \\
$+10,9 \%$ \\
\end{tabular} & \begin{tabular}{|l|}
39265 \\
$+5,10 \%$ \\
\end{tabular} & \begin{tabular}{|l|}
36346 \\
$-7,4 \%$ \\
\end{tabular} & \begin{tabular}{|l|}
35010 \\
$-3,7 \%$ \\
\end{tabular} & \begin{tabular}{|l|}
34856 \\
$-0,4 \%$ \\
\end{tabular} & \begin{tabular}{|l|}
34701 \\
$-0,4 \%$ \\
\end{tabular} & $\begin{array}{r}35448 \\
+2,2 \% \\
\end{array}$ & \begin{tabular}{|l|}
36137 \\
$+1,9 \%$ \\
\end{tabular} \\
\hline $\begin{array}{l}\text { NATO- } \\
\text { Europe }\end{array}$ & $\begin{array}{c}\text { Dollars US } \\
\text { (Million) }\end{array}$ & - & 198329 & \begin{tabular}{|l|}
216088 \\
$+8.9 \%$ \\
\end{tabular} & $\begin{array}{l}\mathbf{2 1 8 9 8 0} \\
+1.3 \% \\
\end{array}$ & \begin{tabular}{|l|}
$\mathbf{1 8 4 3 5 2}$ \\
$-16.0 \%$ \\
\end{tabular} & \begin{tabular}{|l|}
$\mathbf{1 8 8 7 9 7}$ \\
$+2.4 \%$ \\
\end{tabular} & \begin{tabular}{|l}
$\mathbf{1 9 0 6 5 3}$ \\
$+1,0 \%$ \\
\end{tabular} & \begin{tabular}{|l|}
$\mathbf{1 8 9 8 1 2}$ \\
$-0.4 \%$ \\
\end{tabular} & $\begin{array}{l}191620 \\
+0.9 \% \\
\end{array}$ & $\begin{array}{l}191127 \\
-0.3 \% \\
\end{array}$ \\
\hline $\begin{array}{l}\text { United } \\
\text { States } \\
\end{array}$ & $\begin{array}{c}\text { US Dollars } \\
\text { (Million) }\end{array}$ & 247628 & $\begin{array}{r}\mathbf{2 6 0 4 8 7} \\
+10.5 \% \\
\end{array}$ & $\begin{array}{r}349729 \\
+34.2 \% \\
\end{array}$ & $\begin{array}{l}\mathbf{3 5 4 9 5 6} \\
+1.5 \% \\
\end{array}$ & $\begin{array}{l}\mathbf{2 7 8 8 5 6} \\
-21.4 \% \\
\end{array}$ & $\begin{array}{l}257824 \\
-7.5 \% \\
\end{array}$ & $\begin{array}{l}269617 \\
+4.6 \% \\
\end{array}$ & $\begin{array}{l}271491 \\
+0.7 \% \\
\end{array}$ & $\begin{array}{r}\mathbf{3 0 6 3 0 2} \\
+13.0 \% \\
\end{array}$ & $\begin{array}{r}\mathbf{3 2 3 4 1 4} \\
+5.6 \% \\
\end{array}$ \\
\hline $\begin{array}{c}\text { NATO - } \\
\text { Total }\end{array}$ & $\begin{array}{c}\text { US Dollars } \\
\text { (Million) }\end{array}$ & -- & 466393 & $\begin{array}{l}\mathbf{5 7 5 8 2 5} \\
+23,5 \%\end{array}$ & $\begin{array}{l}\mathbf{5 8 4 6 8 1} \\
+1.5 \%\end{array}$ & $\begin{array}{l}\mathbf{4 7 2 2 8 4} \\
-19.2 \%\end{array}$ & $\begin{array}{l}\mathbf{4 5 5 2 7 0} \\
-3.6 \%\end{array}$ & $\begin{array}{l}\mathbf{4 6 8 5 6 4} \\
+2.9 \%\end{array}$ & $\begin{array}{l}\mathbf{4 7 0 0 9 5} \\
+0.3 \%\end{array}$ & $\begin{array}{l}\mathbf{5 0 6 7 3 7} \\
+7.8 \%\end{array}$ & $\begin{array}{l}\mathbf{5 2 3 4 9 8} \\
+3.3 \%\end{array}$ \\
\hline
\end{tabular}

Source : From NATO data ${ }^{15}$

United States have much more fluctuating defence spending, with peaks attributable to their geostrategic situation. European countries know much more regular changes, what shows that the political and strategic determinants of their defence budgets of defence are not similar. The idea of the "leadership" and the execution of the threat explain the erratic progress of the American military

\footnotetext{
${ }^{14}$ NATO (2004), op.cit.

${ }^{15}$ NATO (2004), op.cit. 
expenditures, while Europe, in spite of the "Yugoslavian" affair which revealed large dissensions, has always felt rather in safety, without particular military ambition.

Nevertheless, the differences are high between France and the other NATO European countries. So, if these ones have reduced their defence expenditures of 15,8\% defence between 1990 and 1995, France reduces them only of 7,4 \%. The differences between the NATO European countries' choices on defence may partially explain this ${ }^{16}$. So, the conscription was suppressed as soon as 1991 in Germany, and only in 1996 in France. Germany has chosen an army with a reduced size since the disappearance of the Soviet threat, what allowed it to considerably decrease its military expenditures (Table 3). The French choice of the professional army ensued from the reduction of the risk of invasion and from the necessity of adapting the forces to foreign missions within the framework of international organizations, notably of the NATO, UNO or EPSD. It has induced a lesser reduction of the military expenditures than in other countries. It is to note that the United Kingdom or the United States, which had experienced since long professional soldiers, have known an equivalent decline of their military expenditures between 1992 and 2001 (Table 3).

Table 3 : Defence spending (billions of constant 2001 euros)

\begin{tabular}{|c|c|c|c|c|}
\cline { 2 - 5 } \multicolumn{1}{c|}{} & France & Germany & United-Kingdom & United States \\
\hline $\mathbf{1 9 9 2}$ & 30 & 32.3 & 41.4 & 352.3 \\
\hline $\mathbf{2 0 0 1}$ & 24.9 & 23.8 & 34.1 & 291.9 \\
\hline Variation rate & $-17.0 \%$ & $-26.3 \%$ & $-17.6 \%$ & $-17.14 \%$ \\
\hline
\end{tabular}

Source : Ministère de la défense from NATO data ${ }^{17}$

The graph 2 puts in evidence a constant increase of the share of French military expenditures with regard to those the other NATO countries over the period 1992-1997. This trend is the consequence a decrease of defence spending more belated in France than in the other NATO countries, as well as its lesser intensity at the general level. Even if the share of France begins a decline from 1997, it remains in 2003 higher than in 1984, what shows that the decrease of military expenditures was less important in France than in the other alliance's members. In this country, the political leaders have delayed doing the necessary reforms after the end of the Cold War, because of their will to preserve an independent defence policy.

\footnotetext{
${ }^{16}$ Conan, Matthieu (2002), 'Budget de la défense et réduction des dépenses publiques', Revue Française de Finances Publiques, $\mathrm{n}^{\circ} 79,87$ 110 , p. 92.

${ }^{17}$ Ministère de la Défense (2002, 2003), Annuaire statistique de la défense, Editions 2002 et 2003, chapter V.
} 


\section{Graph 2}

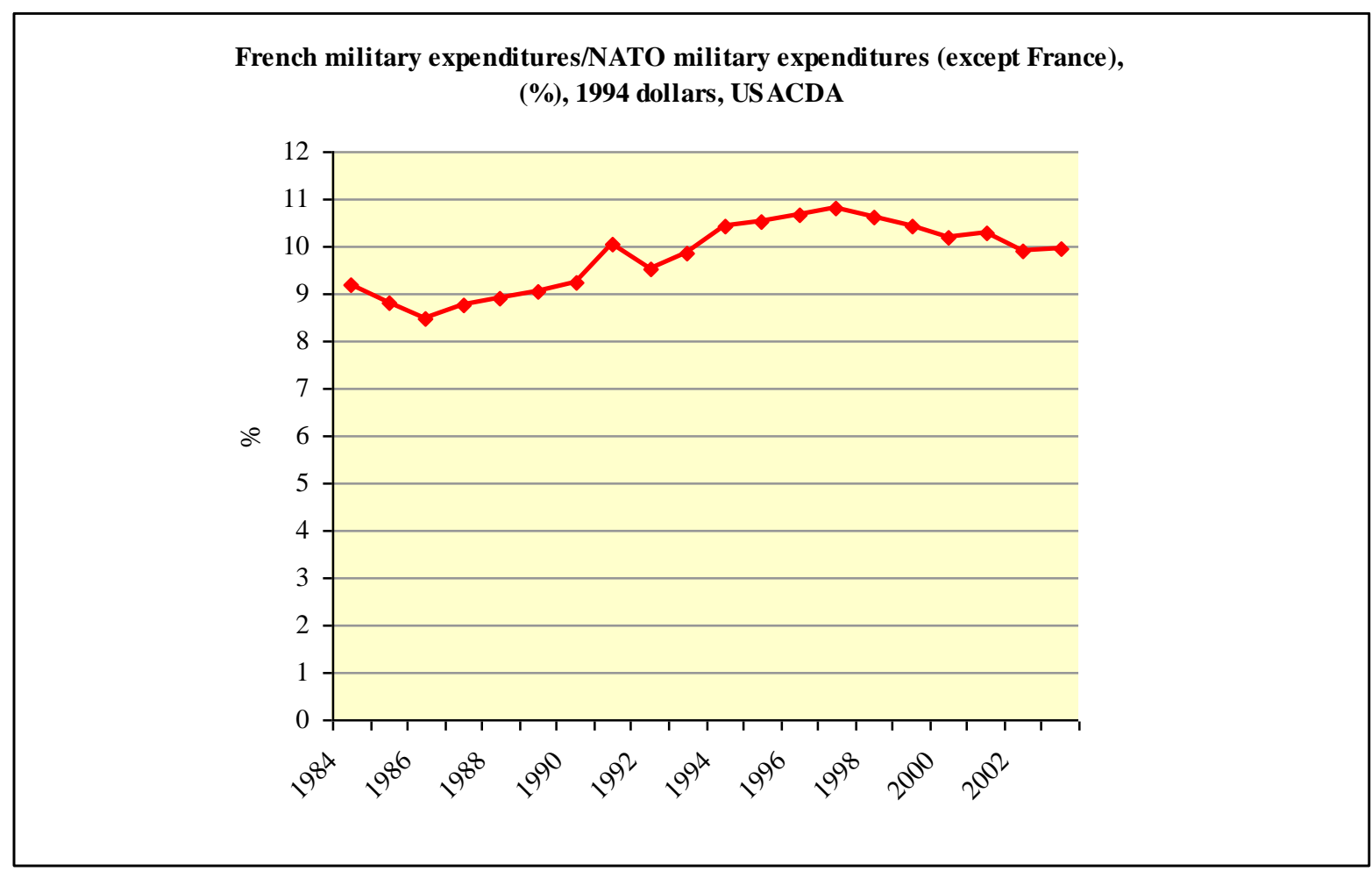

World military expenditures, in particular those of most NATO countries, began an increase from 2000. The reduction of defence budgets during the 1990s was not due to a deep demilitarization of the concerned countries but rather to an alternation of upward and downward cycles, which punctuate the world military expenditures since the 1950s. After 1991, it seemed necessary to establish new strategies, in a more and more competitive economic environment, notably ruled by the World Trade Organization. Countries stayed on the alert, while making a "break" after the cold war ${ }^{18}$.

\section{2) Defence budget and bureaucratic effects}

The ratio of military expenditures to total public spending, concerning the voted amounts in the Initial Law of Finance, is quite stable (between 17 and $19 \%$ ) from 1972 till 1993, then it regularly decreases from 1994 till 2002, followed by a light increase in 2003 and 2004 (cf. Table 4). These figures show the weak variation of the share of military in global public spending and the importance of internal factors in the determination of the defence budget. The weight of defence industries and of the military sector in the national employment and in the GDP, but also the constraints inherent to the maintenance and renewal of armed forces, leave not enough scope for reducing military expenditures. On the other hand, even during the episodes of increased international tensions, for example at the beginning of the 1980s with the freeze of US-USSR relations, military expenditures have never exceeded $19 \%$ of State total expenditures, showing their weak upward elasticity.

Table 4: Share of military expenditures in total public spending in the Initial Law of Finance Voted military expenditures (including pensions) / Total voted public expenditures, \%

\begin{tabular}{|l|l|l|l|l|l|l|l|l|l|l|l|l|l|l|l|l|}
\hline $\mathbf{1 9 7 1}$ & $\mathbf{1 9 7 2}$ & $\mathbf{1 9 7 3}$ & $\mathbf{1 9 7 4}$ & $\mathbf{1 9 7 5}$ & $\mathbf{1 9 7 6}$ & $\mathbf{1 9 7 7}$ & $\mathbf{1 9 7 8}$ & $\mathbf{1 9 7 9}$ & $\mathbf{1 9 8 0}$ & $\mathbf{1 9 8 1}$ & $\mathbf{1 9 8 2}$ & $\mathbf{1 9 8 3}$ & $\mathbf{1 9 8 4}$ & $\mathbf{1 9 8 5}$ & $\mathbf{1 9 8 6}$ & $\mathbf{1 9 8 7}$ \\
\hline 16.59 & 19.09 & 18.38 & 17.45 & 17.93 & 18.1 & 18.12 & 17.53 & 17.33 & 17.42 & 17.36 & 16.10 & 15.66 & 17.79 & 17.87 & 15,03 & 18,75 \\
\hline
\end{tabular}

\footnotetext{
${ }^{18}$ Fontanel, J. (2004), Géoéconomie de la globalisation, Collection Côté cours, UPMF, Grenoble. 


\begin{tabular}{|l|l|l|l|l|l|l|l|l|l|l|l|l|l|l|l|l|}
\hline $\mathbf{1 9 8 8}$ & $\mathbf{1 9 8 9}$ & $\mathbf{1 9 9 0}$ & $\mathbf{1 9 9 1}$ & $\mathbf{1 9 9 2}$ & $\mathbf{1 9 9 3}$ & $\mathbf{1 9 9 4}$ & $\mathbf{1 9 9 5}$ & $\mathbf{1 9 9 6}$ & $\mathbf{1 9 9 7}$ & $\mathbf{1 9 9 8}$ & $\mathbf{1 9 9 9}$ & $\mathbf{2 0 0 0}$ & $\mathbf{2 0 0 1}$ & $\mathbf{2 0 0 2}$ & $\mathbf{2 0 0 3}$ & $\mathbf{2 0 0 4}$ \\
\hline 18.45 & 18.84 & 18.01 & 18.42 & 17.98 & 17.52 & 16.7 & 15,98 & 15,55 & 15,57 & 14.97 & 14.60 & 14.61 & 14.38 & 14.15 & 14.66 & 14.67 \\
\hline
\end{tabular}

Source: Lelièvre V. and Annuaire statistique de la défense $2003^{19}$

As well as the hypothesis of an influence of the external factors on the level of defence spending is debatable, is the one of an influence of internal political factors ${ }^{20}$. The political changes seem to influence only very weakly the level of military expenditures, the great trends of which are drawn by the long-term programs, apart from the electoral cycles. Since the acceptance by two main French political parties of the principle of nuclear deterrence, then of the abolition of conscription, military expenditures do not represent a subject of debate anymore. Finally, one may speak of a relative consensus afterwards. As the United States strengthen their military defence, the French citizen does not worry much about his foreign security, as if the nuclear power, the membership in a pacified Europe and the more than two-hundred years old "friendship" with the United States (in spite of quarrels which can be only temporary, considering the common interests) has ensured a kind of invulnerability towards current threats. This attitude is specific of France, which always intends to be a major political and economic power, by offering in guarantee only its "cultural influence", though declining, and its active role in the European construction.

\section{I.2. French defence budget: a variable of economic adjustment}

As regards the economic variables, French military expenditures rather depend on internal considerations. With the reappraisal of the DGA, the power of the engineers of armament has been gradually reduced. In this context, military expenditures could become "a variable of adjustment". In situation of economic tension, they would be the first ones concerned by a reduction of financial allocations.

\section{1) The gap between the Initial Law of Finance and the budgetary execution for military expenditures}

The Graph 3 below show the difference between the defence budget adopted every year by the Parliament with the Initial Law of Finance and the credits effectively released for the military sector each year, recorded by the Rectified Law of Finance. The executed military expenditures appear to be systematically lower than those who had been planed (graph 3), unlike what happens at the level of the general budget (graph 4). While the executed total public expenditures are systematically and widely superior to those who had been adopted in the Initial Law of Finance, the military sector never succeeds in obtaining the totality of the voted credits. It is obviously explained by the use of military credits as variables of budgetary adjustment. But this also raises the issue of the democratic control of public spending, the successive governments making adopt cancellations of military credits to limit the increase of the public deficit, so modifying the orientations voted by the Parliament.

\section{Graph 3 :}

\footnotetext{
${ }^{19}$ Lelièvre, V. (1996), 'Dépenses militaires et contraintes économiques (1971-1995)', Revue Française d’Economie, printemps, 65-86. and Ministère de la Défense (2002, 2003), op.cit., chapter II.

${ }^{20}$ Foucault, Martial, Le Blanc, Gilles (2004), A political economy approach of defence spending in France : an empirical analysis, presentation at the $7^{\text {th }}$ conference on Economics and Security, Bristol, 26-28 june 2004.
} 


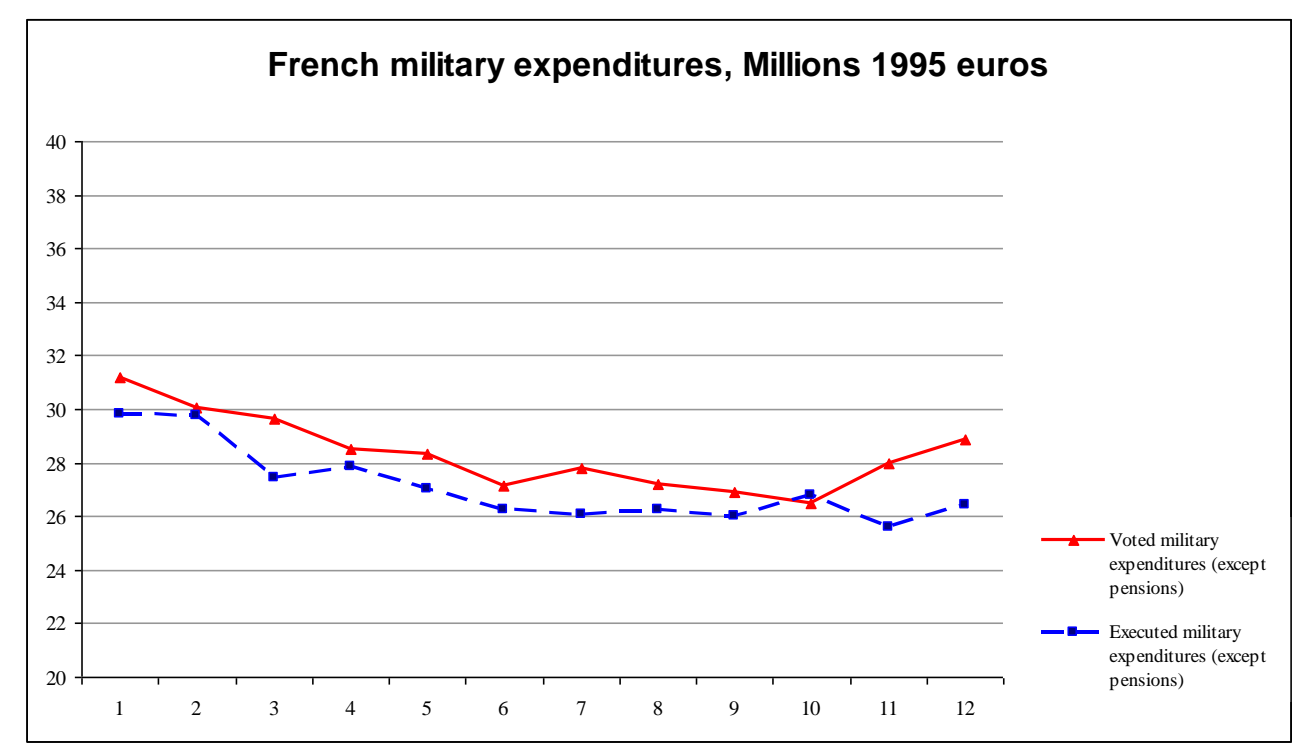

From data of French Ministry of Defence

\section{Graph 4 :}

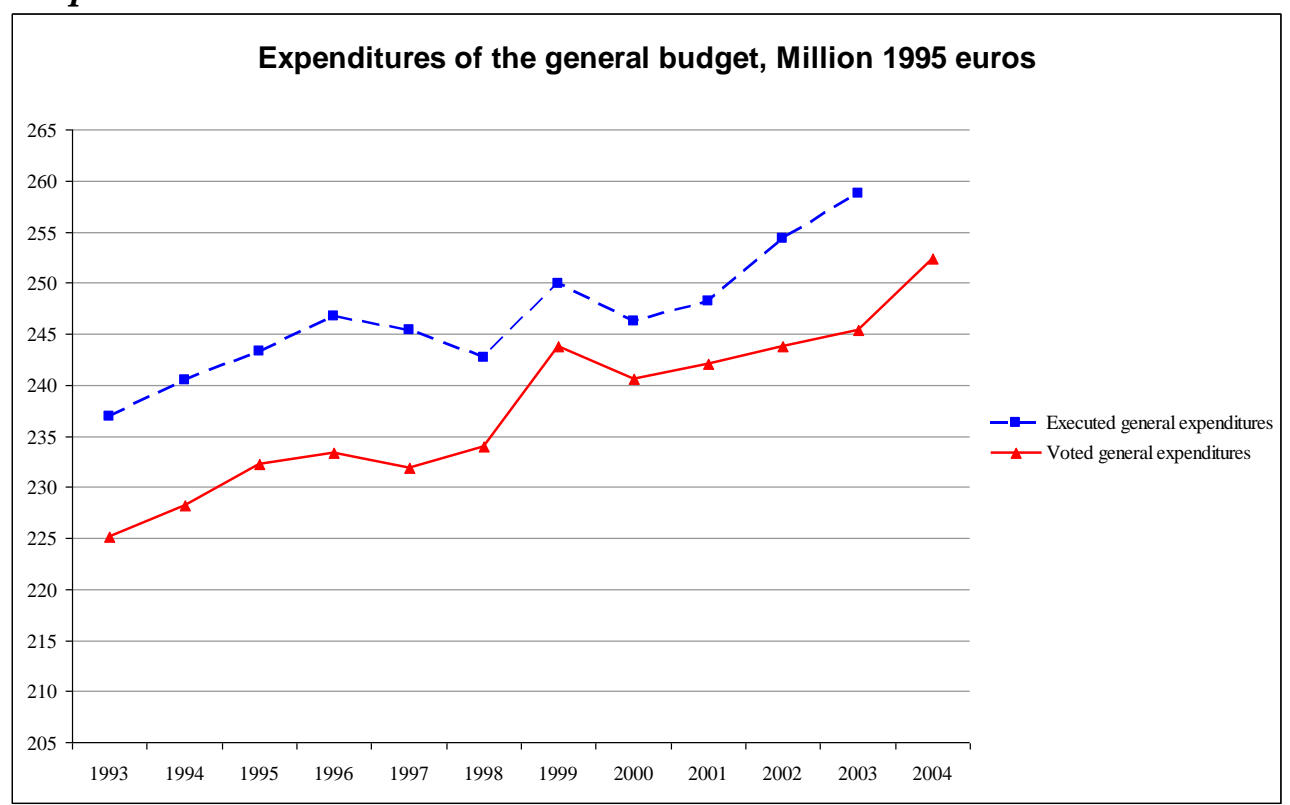

From data of French Ministry of Defence

\section{2) Military expenditures faced with budget cuts}

In a study of 1996, V. Lelièvre ${ }^{21}$ showed that economic constraints strongly affected the level of French military expenditures. From a model comparing the difference between the growth rates of forecasted State receipts and expenses with the growth rate of the GDP, the author tried to put in evidence the neutral, restrictive or expansionist nature of the budgetary impulse. Her study on the period 1970-1994 showed that in France between 1971 and 1995, the defence budget had never been used to reflate the economic activity and that, on the contrary, the defence was one of the first items to bear the brunt of budgetary restriction. As for the budgetary neutrality, it has generally been obtained at the price of a slowing down of military credits, in favour of civil public spending.

\section{The Model:}




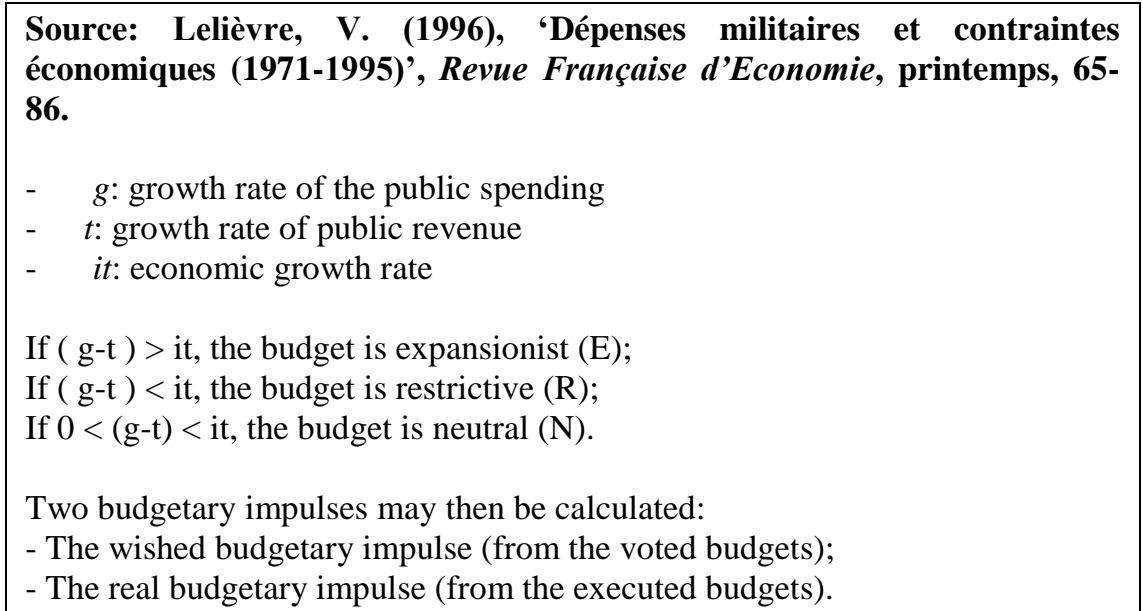

In the table 5, we have continued the comparison of the voted and executed expenditures depending on the nature of the budgetary impulse for the period $1995-2003^{22}$. In our model, $(g-t)$ is given by the variation rate of the State general budget, $B$. The economic growth rate is the variation rate of the Gross Domestic Product, $G$.

We use the following variables:

- $M E v$ : variation rate of the voted defence budget (except pensions), Initial Law of Finance (ILF) $(\%)$;

- MEe: variation rate of executed military expenditures (ordinary and capital expenditures, except pensions), (\%);

- $\quad P S v$ : variaton rate of voted total public spending, ILF (\%);

- $\quad P S e$ : variation of the voted total public spending (\%);

- $\quad B v$ : variation rate of the balance of the voted State general budget, $\operatorname{ILF}(\%)$;

- $B e$ : variation rate of the balance of the executed State general budget (\%);

- $\quad G$ : variation rate of the Gross domestic product (economic growth) (\%);

- $\quad I v$ : nature of the budgetary impulse for the voted budget, with :

E: expansionist,

$\mathrm{R}$ : restrictive,

$\mathrm{N}$ : neutral;

- Ie: nature of the budgetary impulse for the executed budget.

Table 5

\begin{tabular}{|l|l|l|l|l|l|l|l|l|l|}
\hline Année & PSv & $\begin{array}{l}\text { PSe } \\
(\boldsymbol{\%})\end{array}$ & $\begin{array}{l}\text { MEv } \\
(\boldsymbol{\%})\end{array}$ & $\begin{array}{l}\text { MEe } \\
(\boldsymbol{\%})\end{array}$ & $\begin{array}{l}\text { Bv } \\
(\boldsymbol{\%})\end{array}$ & Be (\%) & G (\%) & Iv & Ie \\
\hline $\mathbf{1 9 9 3}$ & 1,82 & 3,03 & 6,78 & $-2,66$ & 4,82 & 6,25 & $-0,89$ & E & E \\
\hline $\mathbf{1 9 9 4}$ & 1,36 & 1,49 & $-3,68$ & $-0,03$ & 10,64 & $-2,44$ & 2,07 & E & R \\
\hline $\mathbf{1 9 9 5}$ & 1,79 & 1,19 & $-1,42$ & $-7,90$ & 0,76 & 1,62 & 1,67 & N & N \\
\hline $\mathbf{1 9 9 6}$ & 0,47 & 1,42 & $-3,79$ & 1,58 & $-3,24$ & $-1,26$ & 1,10 & $\mathrm{R}$ & $\mathrm{R}$ \\
\hline $\mathbf{1 9 9 7}$ & $-0,64$ & $-0,57$ & $-0,58$ & $-2,97$ & $-0,39$ & $-2,19$ & 1,90 & $\mathrm{R}$ & $\mathrm{R}$ \\
\hline $\mathbf{1 9 9 8}$ & 0,90 & $-1,10$ & $-4,15$ & $-2,98$ & $-2,48$ & $-1,17$ & 3,40 & $\mathrm{R}$ & $\mathrm{R}$ \\
\hline $\mathbf{1 9 9 9}$ & 4,19 & 3,020 & 2,28 & $-0,61$ & $-2,51$ & $-3,21$ & 3,21 & $\mathrm{R}$ & $\mathrm{R}$ \\
\hline $\mathbf{2 0 0 0}$ & $-1,28$ & $-1,48$ & $-2,01$ & 0,64 & $-1,41$ & $-1,49$ & 3,79 & $\mathrm{R}$ & $\mathrm{R}$ \\
\hline $\mathbf{2 0 0 1}$ & 0,61 & 0,77 & $-1,22$ & $-0,96$ & $-2,31$ & 0,66 & 2,10 & $\mathrm{R}$ & $\mathrm{N}$ \\
\hline $\mathbf{2 0 0 2}$ & 0,73 & 2,51 & $-1,44$ & 3,02 & 1,39 & 7,14 & 1,21 & $\mathrm{E}$ & $\mathrm{E}$ \\
\hline $\mathbf{2 0 0 3}$ & 0,65 & 1,70 & 5,57 & $-4,29$ & 4,77 & 2,33 & 0,57 & $\mathrm{E}$ & $\mathrm{E}$ \\
\hline $\mathbf{2 0 0 4}$ & 2,81 & & 3,15 & 3,25 & 3,98 & & 3,39 & $\mathrm{E}$ & \\
\hline
\end{tabular}

The study of the period 1993-2004 shows a continuity in the use of military expenditures as variables of budgetary adjustment and in their non-use as an instrument of economic stimulation. So,

\footnotetext{
${ }^{22}$ The variation rates have been calculated with data in constant 1995 euros, from the Annuaire Statistique de la Défense, Edition 2002 et édition 2003, Ministère de la Défense.
} 
five years are characterized by an expansionist budgetary impulse, at the level of the Initial Law of Finance: 1993, 1994, 2002, 2003 and 2004. In 1993, 2003 and 2004, the increase in voted military expenditures is superior to the one in total public spending. However in the budgetary execution, the increase in defence spending remains widely lower than that of total public spending. For example, in 2003, while the rise in the passed defence budget was of 5,57\%, it has been transformed into a decline of $4,29 \%$ in the executed expenditures, showing that the military expenditures serve as variables of budgetary adjustment.

The year 1995 has been marked by budgetary neutrality, which seems to be obtained thanks to a budgetary effort to the detriment of defence. The decline of voted military expenditures is of $1,42 \%$ while total public spending increase is of $1,79 \%$. At the level of the executed expenditures, the decline of military was of $7,90 \%$.

From 1996 till 2001, the general budget adopted by the Parliament has been restrictive. Military expenditures have been particularly affected by budgetary cuts, their decline has been superior to that of all the other public outlays (except in 1997, probably because of the specific political context, with the dissolution of the National Assembly), either they were in decline while the other public spending were increasing. Only 1999 shows an increase of 2,28 \% of the defence budget, lower than the increase of the general budget $(4,19 \%)$, however. In 1997, the decline of the voted military expenditures was worse at the level of the budgetary execution and in 1999, the foreseen rise was transformed into a decline. However at the level of the budgetary execution, the rates show a tendency to reduce the cuts in defence budgets, in 1996, 1998, 2000 and 2001: the reduction of military expenditures was less important than forecasted, and has sometimes been transformed into slight increases.

It is therefore very important to differentiate the voted budget and the executed budget. The increases in military expenditures planed through the military programming of 2003-2008 will so not necessarily become a reality. The fact remains that in 2000, 2002 and 2004, the executed military expenditures were superior to the voted ones, what only rarely happened since the beginning of the 1970s, showing the current will of political authorities to increase the defence effort. This study shows however that in spite of official speeches on the necessity to maintain and increase the French defence potential, invoking strategic and political reasons, the defence budget remains highly subject to economic restrictions and that the discourses are not always followed by the facts.

However, the reminiscences of "Gaullism" and the will of some "left-wing" persons to refuse the model of the pacifists limit the reduction of defence budget. It is as if reducing military expenditures remained synonymic with giving up the national independence, in spite of the European perspectives that gradually limit the importance of this approach. Moreover, the importance of the defence sector in the national economy (notably employment) limits the potential of disarmament.

To summarize our comments, it may be said that today, military expenditures depend on several qualitative factors, such as the European integration, the meaning of the nuclear weapon in the world and in France, the weight of customs and of inertia effects, the political speeches in process of change, but also of the domestic economic growth, the military expenditures of the previous period and the importance granted to jobs in arms firms. But the French defence policy is no more independent and it suffers from many problems.

\section{II- From an independent policy of security to a policy of real dependency}

For a country like France which produces armaments, the internal economic factors therefore seem a priori more determining than the external ones to explain the level of the defence 
spending. France, which is an average power, has given up its idea of a "policy of grandeur" ${ }^{23}$. Today, it has to limit its will of independence and take into account budgetary constraints (for example the respect for the criteria of Maastricht) and economic difficulties. If De Gaulle has once asserted that "the backup would follow", the facts have belied him since long.

\section{II.1. The "potemkinism"24 of French defence policy}

Before the 1990's, the French policy of military independence was notably based on a strong military research and development (R\&D). Many critics have been developed against the too sophisticated technologies obtained in the defence sphere, without any spin-offs in the civil industry, against the capital-intensiveness, without regard to production costs and the excessive secretiveness. But today the economic analysis of the role of military R\&D on the global industrial development has changed. A debatable issue is on the will of French political leaders to lead a real policy of economic power notably based on the military sector, as it has been the case till the 1980's.

\section{1) The weakness of French military research and development (R\&D): from views to reality}

In Europe as in the United States, the armament companies now realize an important part of their sales in the civil sector, what allows them to limit the risks associated to budget cuts in defence. We may think that this new situation facilitates transfers between the military and civil sectors, at the level of human and physical resources, technologies or products. Precisely, the issue of the impact of the military research and development (R\&D) on the growth of the industrial productivity remains polemical. Indeed, the technologies originally developed for defence, as computers and satellite communications, seem to have played an important role in the American growth during the 1990s and to have given them the control of numerous high technologies ${ }^{25}$. However, only few econometric studies developed these last years have put in evidence a link between the growth of the American industrial productivity and the development of these new technologies. For example, the analysis of D. Saal ${ }^{26}$ shows that sophisticated econometric methods may succeed in showing the positive effect of $R \& D$ federal expenditures on the global industrial productivity, since the 1970s. The issue of the impact of the military R\&D on the economic growth has always been very controversial $^{27}$. If it is true that in the short run the patents stemming from the military R\&D seem few, most of the modern technologies have nevertheless been at first developed in the military sector. Also, the increasing use of intelligences for economic purposes may have an impact on the level of military expenditures, especially in the United States where the structures of economic intelligence are particularly developed.

Beyond the statistical debate, this represents an essential stake for the understanding of national economic dynamics, in particular for industrial nations, which devote an important part of their public R\&D to the military sector. France spent in 2003 and 2004 about 2 billions euros on military R\&D, what is less than United Kingdom, with 3 billions. This year marks a new increase of these outlays in France, after an almost continuous decline since 1996, when they had reached a peak at 4,19 billion euros that is more than $30 \%$ of the national spending of R\&D. But this ratio is much lower than the American one: in 2002, 54,4\% of the national R\&D spending was concentrated on the

\footnotetext{
${ }^{23}$ Fontanel, J., Hébert, J.P. (1997) 'The French policy of "Grandeur"', Defence and Peace Economics, Vol. 8, pp. 37-55.

${ }^{24}$ The "potemkinism" is to hide from the sovereign or the citizen, what goes not well, to show only the forces.

${ }_{25}$ Alesina, A., Giavazzi, F. (2004), 'Inégalité de l'Europe en matière d'investissement de défense', Project Syndicate, http://www.projectsyndicate.org/article print text?mid=842\&lang=4.

${ }^{26}$ Saal, D. (2001), 'The impact of procurement-driven technological change on U.S. manufacturing productivity growth', Defence and Peace Economics, 12(6), pp. 537-568.

${ }^{27}$ Fontanel, J. (1997), 'Eléments de réflexion sur la conversion des technologies militaires, Structures industrielles et mondialisation', Innovations, 5,1. Fontanel, J. et Karlik, A. (2005), 'L'industrie d'armement de la Russie. Effondrement ou renouveau ?', Innovation, 20, 81108 .
} 
military R\&D in United States, and only $24,2 \%$ in France ${ }^{28}$. The use of military expenditures for "industrial policy" purposes may be considered as one explanatory factor of their level in United States.

Table 6: Compared expenditures of military research, except nuclear, in billion euros

\begin{tabular}{|l|l|l|l|l|l|}
\cline { 2 - 6 } \multicolumn{1}{c|}{} & $\mathbf{1 9 9 9}$ & $\mathbf{2 0 0 0}$ & $\mathbf{2 0 0 1}$ & $\mathbf{2 0 0 2}$ & $\mathbf{2 0 0 3}$ \\
\hline France & 2.15 & 2.03 & 2.11 & 1.85 & 1.99 \\
\hline United Kingdom & 3.51 & 3.81 & 3.91 & 3.35 & 2.95 \\
\hline Germany & 1.19 & 1.22 & 1.15 & 0.85 & 1.08 \\
\hline
\end{tabular}

Source: National Assembly, Report on the Project of Law of Finance for $2004^{29}$.

According to the law of military programming for 2003-2008, this increase of the military R\&D budget should continue at least until 2005. It is moreover necessary to take into account the fact that 1,9 billion euros of the public R\&D budget have been allocated to the military sector in $2003^{30}$. Indeed, "one tier of the companies financed by the defence programs are also financed by the great technological programs", according to a report in 2001 of the Ministry of Research ${ }^{31}$, what shows that the French industrial policy through great programs is still relevant today, although more and more concentrated on defence, as it is already the case for the United States.

But today France remains behind Anglo-Saxon countries on military R\&D. This problem is not only national but also European. Indeed, a report of the Observatoire Economique de la Défense in 2002 uses the concept of "technological disarmament" in Europe, beyond a mere "technological gap" with the United States. If the military expenditures of European countries represented $40 \%$ of American expenditures, the rate was only of $25 \%$ for R\&D spending and $12,5 \%$ for R\&T spending. Moreover, American enterprises have an advantage coming from a strong support of their State on R\&D, notably in aerospace.

\section{2) A difficult industrial adaptation to the new security and economic environment}

The French arms production has been until the mid-1990s characterized by an "administrated regulation", with the supervision of the D.G.A. (General Delegation of Armament). The role of this organization is minimized in the "White Book" of 1994, while it had been until then placed in the heart of the industrial policy of armament ${ }^{32}$. The text recommends new relations between the State and the arms firms, with a decrease of the supervision and of the "mentality of arsenal". The organization of armament production in France has actually undergone profound changes, the DGA not being the interface between military staffs and industries anymore. The markets have been opened to competition, so as to limit the drift of programs costs. The operations of restructuring and integration, notably through mergers with other European firms, have reinforced this trend. According to J.P. Hébert, this reform marked "the end of the French administered regulation and the beginning of the economic calculation».

In spite of these changes, the French and European arms industry has been penalized after 1990 by too narrow markets structured on a national basis. Moreover, it has suffered from the industrial dependency on public orders, in the context of European public funds restrictions. And yet the costs of research, development and production of military materials were rising. Data show a decrease in

\footnotetext{
28 D'après Perrier, J.J. (2003), 'Que pèse le militaire dans la recherche française ?', Revue du Vivant n 1 , Www.vivantinfo.com/numero1/recherche militaireimp.html. Chiffres de l'OCDE 2003, base MSTI.

${ }^{29}$ Assemblée Nationale (2003), Rapport sur le projet de Loi de Finances pour 2004 par M. Gilles Carrez, n 110 , Première Partie, Annexe $\mathrm{n}^{\circ} 40$, enregistré le 9 octobre 2003, 56 pages, p. 55.

${ }^{30}$ Rapport au Sénat $\mathrm{n}^{\circ} 117$ sur la loi de programmation militaire 2003-2008.

${ }^{31}$ Ministère d'éducation nationale, de l'enseignement supérieur et de la recherche (2003), 'Recherche \& Développement en France. Résultats 2000, estimations 2001 et objectifs socioéconomiques du BCRD 2002', Evaluation et Statistiques, Les Dossiers, n 144 , juin.

${ }^{32}$ Hébert, J.P. (1998), 'La réforme de la politique de défense et l'industrie française d'armement', in Debezies, P., Klein, J., La réforme de la politique française de défense, Economica et Institut de Stratégie comparée, www.stratisc.org, site of the strategy in history. 
French arms exports since the 1990s, as well as a reduction of the turnover and of the employments of the arms industry (graphs $4,5 \& 6$ ).

\section{Graph 5}

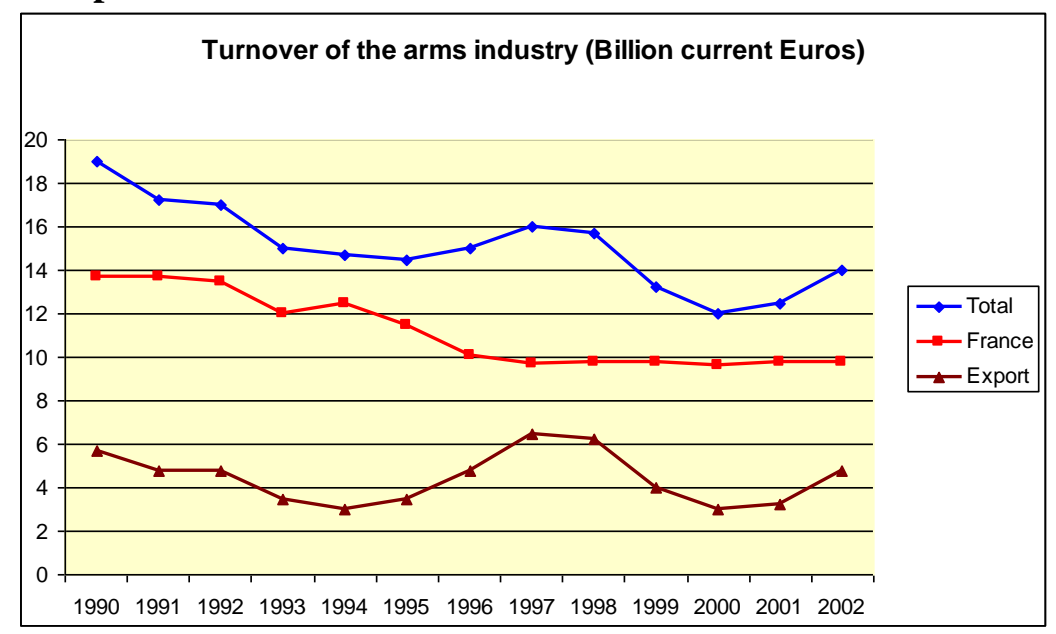

\section{Graph 6}

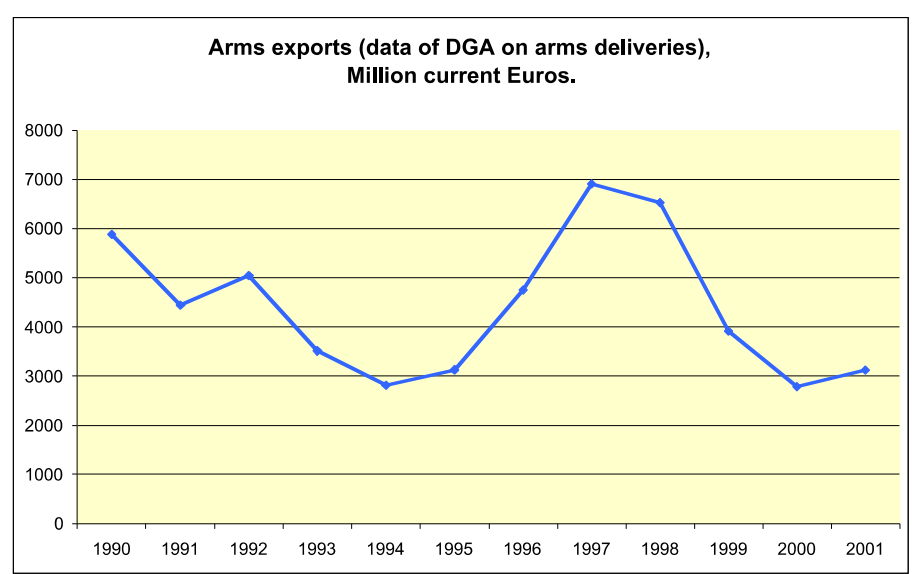

\section{Graph 7}

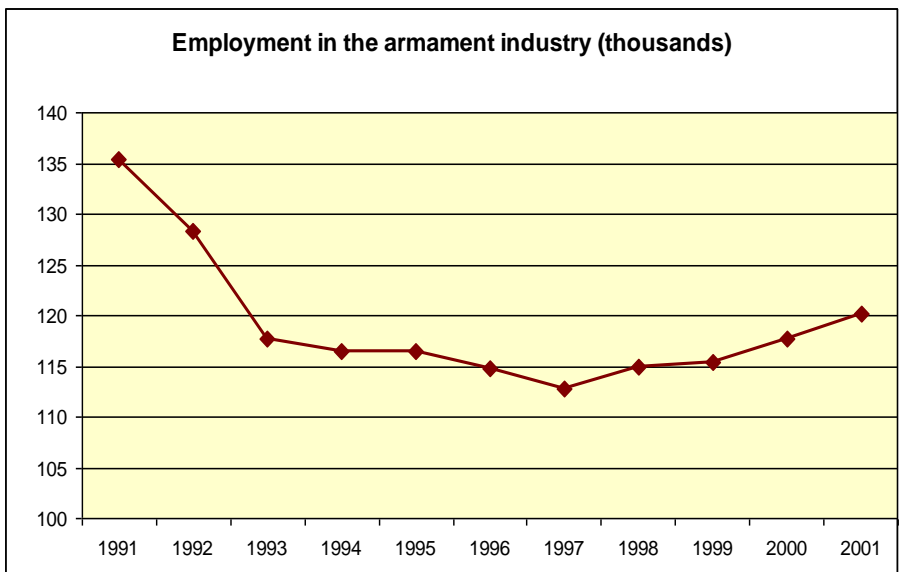

Source for graphs 5, 6 and 7. From data of the Ministry of Defence, Annuaire Statistique de la Défense, Editions 2002 \& 2003. The armament industry (BA95) includes three industries: shipbuilding; aircraft and space manufacturing; weapons and ammunitions manufacturing. It therefore include both civil and military activities ${ }^{33}$.

Table 7: The French defence industrial base in 2002

\begin{tabular}{|c|c|c|c|}
\hline Firm & $\begin{array}{l}\text { Turnover } \\
\text { in } 2002 \\
(\text { million } €)\end{array}$ & Workforce & Main activities \\
\hline $\begin{array}{c}\text { Dassault-Aviation } \\
\text { Group }\end{array}$ & 3437 & 12000 & $\begin{array}{l}35 \%: \text { military aircraft } \\
65 \%: \text { civil aircraft }\end{array}$ \\
\hline$\overline{\mathrm{DCN}}$ & 2200 & 14200 & $\begin{array}{c}45 \% \text { : new manufacturing } \\
25 \% \text { : combat systems and equipments } \\
30 \% \text { : maintenance in operational condition }\end{array}$ \\
\hline $\begin{array}{l}\text { GIAT Industries } \\
\text { Group }\end{array}$ & 777 & 6200 & $\begin{array}{c}81,3 \%: \text { amoured systems } \\
14,7 \%: \text { arms, ammunitions } \\
3 \%: \text { R\&D } \\
1 \%: \text { other }\end{array}$ \\
\hline SAGEM Group & 2763 & 12097 & $\begin{array}{c}64 \%: \text { communication } \\
36 \%: \text { defence and security }\end{array}$ \\
\hline SNECMA Group & 6504 & 38986 & $\begin{array}{l}64,2 \% \text { : aerospace propulsion } \\
37,8 \% \text { : aeronautic equipments }\end{array}$ \\
\hline
\end{tabular}

\footnotetext{
${ }^{33}$ Ministère de la défense (2002), op.cit., p. 9
} 


\begin{tabular}{|c|c|c|c|}
\hline SNPF Group & 830 & 5573 & $41 \%:$ light chemistry \\
& & & $32 \%:$ energy materials \\
& & $14 \%:$ chemistry specialities \\
& & $13 \%:$ explosives \\
\hline Thales Group & 11105 & 60600 & $\begin{array}{c}61 \%: \text { defence } \\
16 \%: \text { aeronautics }\end{array}$ \\
& & & (5\% of which for military applications) \\
& & $23 \%$ IT\&S \\
\hline
\end{tabular}

Source: Ministry of Defence, Annuaire statistique, Edition 2003, chapter IV.

In this context of decreasing means and efficiency, France has tried to set up an European system of defence, allowing to compensate for the shortcomings of national systems, notably for heavy materials, like transport planes or ships, or aircraft carriers (France proposed at the end of 1998 the creation of an European air and sea group gathering all national aircraft carriers), and for "transmission and intelligence" (France had a leading role in the programs Hélios 1 and Hélios 2). However, European cooperation have remained limited, because of the reluctance of some allied governments attached to the transatlantic link and of their preference for cooperation on American programs, as shown by the Joint Strike Fighter project.

The ambition of France with regard to the European defence policy has therefore not immediately led to concrete realizations, the other "natural" allies not being ready for the implementation of a common defence outside NATO. The setting up of an independent European defence within NATO (EUO) also seems delicate, as shown by the non-intervention of the EUO in 1991 in former Yugoslavia.

Unlike in Germany or United Kingdom, the French state has much delayed his withdrawal from the main companies in aerospace and defence electronic (like in Italy and Spain), though it seemed necessary after 1991 to open up the national arms markets and to create a defence industry at the European scale, so as to remain technologically competitive in front of the United States. The first wave of privatization and integration has led to three main European groups: BAE systems, Thales, EADS. However, many overcapacities remain in the land and naval sectors, to the benefit of American industries. The size of European companies remain insufficient in front of US ones, and their product range are not large enough to be competitive on many market segments.

Moreover, the benefits should be limited, in the lack of a real integrated European industrial and budgetary policy. The reticence of the main European states about the opening to international competition of public invitations to tender should limit the reforms. European states, and notably France, remain concerned about the maintaining of the domestic industrial basis, and therefore of a national source of supply. The creation of European integrated companies progressively modifies this, as they have a larger access to the national markets of their components. However, today, the United Kingdom is the single country to organize an international competition for its national programs of equipment, with some restrictions.

Beyond the industrial base issue, one may think more generally that France model of economic power remains weak. It is notably shown by the inadequacy of the French policy on "economic intelligence", a field were industrial and public interests are closely linked. Admittedly, the existence of a system of communication interception, ironically nicknamed the "Frenchelon" by US officials, may explain the weak criticism of the American system by French political leaders. But beyond, French resources of economic intelligence seems much limited. A new report ${ }^{34}$ published on this issue in 1994 and 2003 have warned against the lack of a national system of economic structures of economic intelligence and, more largely, of economic security. It is much significant that the concept of economic security remains defined by the "Ordonnance" of 1959, which limits its use to issues of economic or industrial espionage from enemy countries. Many affairs have alerted the leaders on the risks for long-term economic growth of an insufficient protection of key-enterprises.

\footnotetext{
${ }^{34}$ Carayon, B. (2003), Intelligence économique, compétitivité et cohésion sociale, Rapport au Premier Ministre, La Documentation Française, Paris. 
Though, the control taken by American assets of the French firm Gemplus, inventor of the chip card, has led to a change in the French legislation. But a policy of economic intelligence may not be limited to defensive systems, it must also allow the economic offensive. Today, the advances of France in this field remain few, in comparison with other countries, such as the United States, Japan or Germany ${ }^{35}$. Many links between the military sector and the civil sector remain unexploited at this level.

\section{II.2. France's defence model in difficulty: the meaning of the military expenditures' structure}

The current changes in military sector show that France does not lead a clear and ambition defence policy anymore. Beyond the promises, data reveal a transformation of the structure of military expenditures, significant of the country's difficulties to redefine the role of military sector in a context of increased competition. The nuclear issue is revealing of the difficulties of the French defence model.

\section{1) A declining share of capital expenditures in the defence budget}

The White Book on the National defence, published in 1994, shows an intention of continuity in the defence policy, insisting on the strengthening of conventional armaments and nuclear deterrence. The implementation of the European Policy of Security and Defence seems to justify the preservation of the defence budget at previous levels ${ }^{36}$. But in reality a cut in the initial military budgets adopted by the Parliament has been operated, through a cut in the credits of equipment (cf. table 8). Actually, equipment expenditures are very elastic in global military expenditures. When there is an effort to reduce the military budget, functioning expenditures undergo strong inertia effects which lead the government to suppress or delay the renovation of arms heavy materials.

These changes in the structure of military expenditures may notably be explained by the transition to a professional army from $1996^{37}$. The delay of the professionalization with regard to other countries as the United Kingdom moreover partially explains the delay in military expenditures reduction. So, with more than $60 \%$ of its military expenditures devoted to personnel expenditures, France suffers a gap with regard to the Anglo-Saxon countries having chosen much earlier the professional army, their rate of personnel expenditures being lower than $40 \%$ (cf. Tables 9 and 10).

Table 8

Variation rate of defence budget and capital expenditures, Initial Law of Finance, from data in constant euros

\begin{tabular}{|l|l|l|}
\hline Year & $\begin{array}{l}\text { Defence } \\
\text { budget }(\%)\end{array}$ & $\begin{array}{l}\text { Capital } \\
\text { expenditures } \\
(\%)\end{array}$ \\
\hline 1993 & $-0,13$ & $-2,27$ \\
\hline 1994 & $-2,88$ & $-9,39$ \\
\hline 1995 & $-1,28$ & $-1,58$ \\
\hline 1996 & $-2,24$ & $-7,60$ \\
\hline 1997 & $-0,49$ & $-1,63$ \\
\hline 1998 & $-3,00$ & $-9,47$ \\
\hline
\end{tabular}

\footnotetext{
${ }^{35}$ Bensahel, L. (2005), Intelligence économique, Fragments de cours, UPMF, Grenoble.

${ }^{36}$ Conan, Matthieu (2002), 'Budget de la défense et réduction des dépenses publiques', Revue Française de Finances Publiques, n 79,87 110 , p. 90.

${ }^{37}$ During the 1980's, the expenditures of functioning were lower than expenditures of equipment, infrastructure and research-development. It was the price to pay for the French strategy of deterrence "du faible au fort", characterized by a strong independence of choices and very high investments, given the weak economies of scale. However, this situation was possible thanks to the excellent ratio quality/price of conscription.
} 


\begin{tabular}{|l|l|l|}
\hline 1999 & 1,66 & 5,56 \\
\hline 2000 & $-1,24$ & $-4,46$ \\
\hline 2001 & $-0,97$ & $-1,21$ \\
\hline 2002 & $-0,87$ & $-5,17$ \\
\hline 2003 & 4,23 & 9,16 \\
\hline 2004 & 2,88 & 8,02 \\
\hline
\end{tabular}

Source : Ministère de la Défense $e^{38}$

Table 9 : Total defence expenditures devoted to personnel expenditures (\%)

\begin{tabular}{|l|l|l|l|l|l|l|l|l|l|}
\cline { 2 - 10 } \multicolumn{1}{c|}{} & $\begin{array}{l}\text { Average } \\
\mathbf{1 9 8 0 - 4}\end{array}$ & $\begin{array}{l}\text { Average } \\
\mathbf{1 9 8 5 - 9}\end{array}$ & $\begin{array}{l}\text { Average } \\
\mathbf{1 9 9 0 - 4}\end{array}$ & $\begin{array}{l}\text { Average } \\
\mathbf{1 9 9 4 - 9}\end{array}$ & $\mathbf{1 9 9 9}$ & $\mathbf{2 0 0 0}$ & $\mathbf{2 0 0 1}$ & $\mathbf{2 0 0 2}$ & $\mathbf{2 0 0 3}$ \\
\hline France & -- & - & -- & 58,2 & 60,3 & 60,4 & 60,5 & 60,7 & 58,8 \\
\hline Germany & 46,6 & 48,9 & 57,4 & 61,5 & 59,8 & 60,7 & 60,3 & 59,4 & 60,4 \\
\hline Italy & 59,1 & 57,8 & 63,6 & 71,8 & 74,0 & 71,4 & 72,3 & 74,0 & 73,7 \\
\hline U.K. & 37,4 & 38,6 & 42,2 & 39,4 & 37,9 & 38,2 & 38,7 & 40,0 & 39,7 \\
\hline U.S.A. & 41,9 & 37,0 & 39,3 & 39,0 & 38,1 & 37,7 & 36,2 & 36,1 & 35,3 \\
\hline
\end{tabular}

Source : From NATO data ${ }^{39}$

Table 10 : Total defence expenditures devoted to equipment expenditures (\%)

\begin{tabular}{|l|l|l|l|l|l|l|l|l|l|}
\multicolumn{1}{c|}{} & $\begin{array}{l}\text { Average } \\
\mathbf{1 9 8 0 - 4}\end{array}$ & $\begin{array}{l}\text { Average } \\
\mathbf{1 9 8 5 - 9}\end{array}$ & $\begin{array}{l}\text { Average } \\
\mathbf{1 9 9 0 - 4}\end{array}$ & $\begin{array}{l}\text { Average } \\
\mathbf{1 9 9 4 - 9}\end{array}$ & $\mathbf{1 9 9 9}$ & $\mathbf{2 0 0 0}$ & $\mathbf{2 0 0 1}$ & $\mathbf{2 0 0 2}$ & $\mathbf{2 0 0 3}$ \\
\hline France & -- & -- &.-- & 21,3 & 19,4 & 18,9 & 19,4 & 19,1 & 20,6 \\
\hline Germany & 20,0 & 19,6 & 13,5 & 11,8 & 13,2 & 13,5 & 14,0 & 14,1 & 14,0 \\
\hline Italy & 17,4 & 19,7 & 16,3 & 12,9 & 11,7 & 14,3 & 10,3 & 12,4 & 12,7 \\
\hline U.K. & 26,2 & 24,8 & 21,0 & 24,8 & 26,9 & 25,7 & 24,2 & 23,6 & 23,5 \\
\hline U.S.A. & 21,9 & 25,6 & 25,1 & 26,2 & 24,9 & 21,9 & 25,7 & 27,4 & 27,6 \\
\hline
\end{tabular}

Source : From NATO data ${ }^{40}$

The efficiency of military expenditures depends on the distribution among the various budget items. So, the European countries having military expenditures $60 \%$ of which are of personnel, what is the case of France, have "less effective" expenditures than those of the Anglo-Saxon countries, the rate of which is much lower. Besides, the European industries of defence can be considered as remaining too much divided to effectively compete with the American ones. On the evolution of the defence policy at the European level will also depend the future of the military production in France and thus, more widely, of the military sector and expenditures, the economic aspect being a factor of these expenditures.

\section{2) A decreasing investment in the nuclear field}

Giving up its strategy of non-participation in nuclear disarmament agreements, in 1996 the government has decided the end of ground to ground systems as well as of nuclear tests (after an ultimate simulation in Mururoa), but also plants closure and the reduction of submarine capacities. However, the nuclear deterrence however remains central in the French defence strategy, as reasserted by Jacques Chirac in 2004: "The nuclear deterrence is at the heart of the means which allow France to assert the principle of strategic autonomy, from which our defence policy ensues. It is today, thanks to the efforts granted in a continuous way since the General de Gaulle, an essential foundation of our security and it will remain so, in my opinion, still during long years in the new strategic context where it keeps all its sense and all its efficiency. The nuclear deterrence is at first an important factor of the international stability (...), ${ }^{\prime 41}$ The nuclear deterrence is presented as an essential answer to the threats

\footnotetext{
${ }^{38}$ Ministère de la Défense (2002, 2003), op.cit., chapter V.

${ }^{39}$ NATO (2004), Defence expenditures of NATO countries, www.nato.int/docu/pr/2003/p03-146e.htm

${ }^{40}$ op.cit.

${ }^{41}$ Speech of Jacques Chirac, president of the Republic in front of the IHEDN (Institute of High Studies on National Defence), June $8^{\text {th }}, 2001$.

"La dissuasion nucléaire est au Coeur des moyens qui permettent à la France d'affirmer le principe d'autonomie stratégique, dont découle notre politique de défense. Elle est aujourd'hui, grâce aux efforts consentis de manière continue depuis le général de Gaulle, un fondement essentiel de notre sécurit é et elle le restera, à mon sens, pendant de longues années encore dans le nouveau contexte stratégique où elle garde 
represented by some regional powers, in the context of the development of weapons of mass destruction (ballistic proliferation, new nuclear, biologic or chemical weapons, etc.

However, the credits opened for nuclear deterrence have been much reduced since 1990 and reached their lowest level in 2001. In constant 2003 euros, the funds of payment for nuclear amounted 5,94 billion euros in 1990 and 2,96 in 2003, what means they have been divided in real terms by a factor twofold. The decrease of the importance of nuclear deterrence in Titre V (equipment and infrastructure expenditures), 21,7\% in 2003, should continue at least until 2008 (when it should represent 17\%).

According to the Ministry of Defence, French nuclear forces are now designed to be "strictly sufficient”.

\section{Conclusion}

It appears that the situation of the military sector has much evolved since the mid1980s. The French model of a protected arms production and exports has given place to a competitive environment, with higher budgetary constraints in the context of the European Union. In 2005, France is far from its past "policy of grandeur". Now, the national military strategies remain vague, still impeded by inertia effects, bureaucracy and electoral aims.

Our study has shown that French military expenditures are mostly dependent on internal factor, and notably on economic considerations, what is explained by two facts:

- The reform of the French defence policy has taken a long time. Indeed, it became effective only in 1996, what accounts for the belated reaction to the end of the Cold War of French military expenditures, with regard to other NATO countries.

- Besides, our study on the period 1995-2003 shows that military expenditures are often subject to budgetary restrictions, more than other public spending, what contrast with the official speeches reasserting the importance of defence in French foreign policy.

The defence sector has therefore become more an economic burden than a driving force. The structure of military expenditures indicates the weaknesses of the French defence model, with the reduction of the share of equipment expenditures, as well as of the one of the nuclear budget. The insufficiencies concerning military R\&D and economic intelligence in comparison with other NATO countries must also be evoked. Moreover, the restructuring of the arms industry has been more delayed in France than in United States or United Kingdom. The policy of security is not independent anymore; it is now characterized by a real dependency on armaments and strategies.

It may then be considered that French military expenditures have no other logic than that of "potemkinism" (notably on the nuclear issue), with a short-term perspective and of the electioneering. The long-term perspectives are little evoked in spite of the military programming, so little respected. It is not sure that such an attitude is a correct basis for France's military policy.

tout son sens et toute son efficacité. La dissuasion nucléaire est d'abord un facteur important de la stabilité internationale. (...)" www.ladocfrancaise.gouv.fr/dossier international/nucleaire/debats/dissuasion.shtml 